ENTREPRENEURSHIP AND SUSTAINABILITY ISSUES

ISSN 2345-0282 (online) http://jssidoi.org/jesi/

2021 Volume 8 Number 3 (March)

http://doi.org/10.9770/jesi.2021.8.3(12)

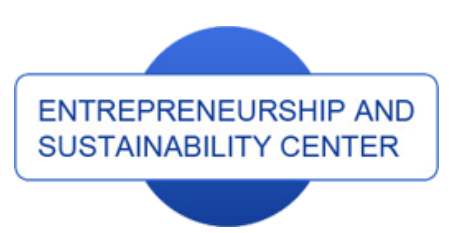

Publisher

http://jssidoi.org/esc/home
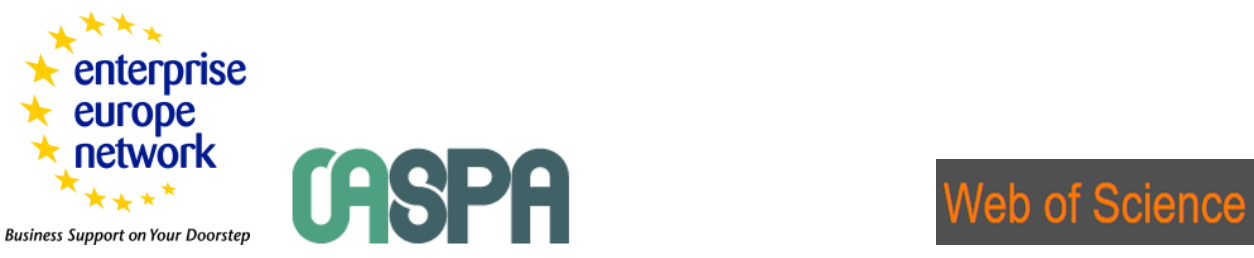

I Clarivate

Analytics

\title{
CHARACTERISTICS OF DISTANCE WORK ORGANIZATION IN SMES DURING THE COVID-19 LOCKDOWN: CASE OF WESTERN LITHUANIA REGION*
}

\author{
Giedrè Strakšienè ${ }^{1}$, Henrika Ruginè ${ }^{2}$, Laura Šaltytė-Vaisiauske் ${ }^{3}$ \\ 1, 2, 3 Klaipeda University, H. Manto 84, Lithuania \\ E-mails:.'giedre.straksiene@ku.lt $;{ }^{2}$ henrika.rugine@ku.lt ; $^{3}$ laura.saltyte-vaisiauske@ku.lt
}

Received 10 December 2020; accepted 28 January 2021; published 30 March 2021

\begin{abstract}
The article is based on the findings of the applied research project Assessment of the Effectiveness of COVID-19-Related Restrictions on Economic Activity and the Impact of State Intervention Measures on Enterprises in the Klaipeda Region (No. P-COV-2051). The aim of the research is to reveal the characteristics of distance work in small and medium business enterprises of Klaipeda Region in the context of COVID-19. The main research question focuses on how the variety of work activities be realized in distance way and to what extent is it effective? To identify the situation, a mixed research methodology, quantitative (questionnaire) and qualitative (focus group) research methods were used. 73 business entities participated in the survey, and 7 focus group discussions were organised remotely in 7 municipalities, with the participation of 61 respondents (on average, 8 in each group). The research findings revealed that the problems of distance work in SME's were generally an under-researched topic, and the definition and concept of distance work varied. Problems emerged that could be divided into two subgroups: the first related to the IT infrastructure(a shortage of equipment, Internet disruption and the resulting increased costs), while the second subgroup concerned mainly human factors (the issues of employees' communication skills and attitudes or emotions when working remotely, lack of methodology for organising distance work, etc.). It is worth adding that, in the course of the current research, identification of a broader field of problems and discussions of their causes were possible due to the cooperation of researchers-representatives of various scientific areas.
\end{abstract}

Keywords: distance work; COVID-19; small and medium enterprise (SME)

Reference to this paper should be made as follows: Strakšienè, G., Ruginè, H., Šaltytė-Vaisiauskè, L. 2021. Characteristics of distance work organization in smes during the Covid-19 lockdown: case of western Lithuania region. Entrepreneurship and Sustainability Issues, 8(3), 210-225. http://doi.org/10.9770/jesi.2021.8.3(12)

JEL Classifications: O32, O33, O15, O11

\footnotetext{
${ }^{*}$ This research was funded by Lithuania Research Council, grant number P-COV-20-5
} 


\section{ENTREPRENEURSHIP AND SUSTAINABILITY ISSUES}

ISSN 2345-0282 (online) http://jssidoi.org/jesi/

2021 Volume 8 Number 3 (March)

http://doi.org/10.9770/jesi.2021.8.3(12)

\section{Introduction}

The idea of distance-work (referred to also as e-work; telework, remote work) is closely related to the development of the knowledge society in Europe. The Lisbon Strategy (2000) highlighted the importance of creating "to become the most dynamic and competitive knowledge-based economy in the world by 2010 capable of sustainable economic growth with more and better jobs and greater social cohesion and respect for the environment". Burbules and Callister (2000) argued that the Internet had been increasingly becoming a working space where common tasks could be developed and simulation and visualisation-based information could be designed, able to show interaction in a complicated situation.

In the early 21 st century, about $27 \%$ of new jobs were created using flexible forms of employment in the United States (about 18\% in the EU), and the role of such forms has been steadily growing (Gruževskis, 2001). Typical forms of such a type of employment are usually characterised by non-standard working time, specific employment contracts, or other less common employment and/or labour relations; they appear to be the least popular in Bulgaria, Estonia, and Latvia (accounting for approximately 13-15\%) (Miežienè, Gruževskis, 2016). According to Nakrošienè and E. Butkevičienè's (2016) survey performed in 2015, 12,5 \% of the respondents tried to combine distance and face-to-face work, while part of them $(9,3 \%)$ spent most of the working day either in their offices or other workplaces that were not at home. The research data proved that, in Lithuania, only $2 \%$ of the respondents worked fully from home. In accordance with Eurostat results, employees that usually worked from home accounted for approximately $0.9 \%$ of all employees in 2015. That type of employment had insignificantly decreased in Lithuania over the past years. As demonstrated by Eurostat figures, working from home was much more widespread in other EU countries (in 2015, the EU-28 average was 2.5\%). The highest prevalence of working from home was found in the Netherlands (with 8.4\% employees regularly working from home in 2015), Finland (7.5\%), Austria, and Denmark (5.9\%), whereas Bulgaria, Romania, and Latvia reported the lowest prevalence of that type of employment $(0.2 \%, 0.4 \%$, and $0.5 \%$, respectively) (Miežienė, Gruževskis, 2016). The draft LLC (the Lithuanian Labour Code) approved on 21 June 2016 contained, in addition to other novelties, certain amendments to the types of employment contracts (Miežiené, Gruževskis, 2016).

With the onset of the COVID-19 pandemic and lockdown, the sudden increase in the number of distance workers in various companies and institutions became a serious test. Research in distance work proved that in Lithuania, similarly to Europe about $40 \%$ of people on average worked remotely during the pandemic. It must be agreed that the COVID-19 pandemic made it possible to quickly and to a large extent reveal the advantages and disadvantages of distance work in the Lithuanian labour market. Kwon and Jeon (2020) researched that for successful implementation of telework programs, leaders, managers, and supervisors should provide consistent and substantive support for telework programs. For instance, they can develop appropriate legal and policy guidelines to facilitate tools that encourage cooperation, collaboration, and virtual interactions with and among teleworkers who may easily feel isolated due to a lack of interaction with coworkers.

One of the main issues of the contemporary distance work is being aware of requirements of constantly changing life and work, understanding trends of ICT development and managing to apply them for distance work in order to improve working quality. It is often discussed whether distance work keep up with ICT development and make opportunities offered by them? Another important question is, can the variety of work activities be realized in distance way and to what extent is it effective?

The above circumstances make it possible to argue that distance work in SMEs, as the object of research, is specific. On the one hand, the inadequacy of such research is due to the diversity of the concept of distance work, still prevalent in social sciences (distance work, e-work; telework, remote work), on the other hand, the research is encumbered by the fact that the COVID-19 pandemic has not ended and that economic restrictions are still in 


\section{ENTREPRENEURSHIP AND SUSTAINABILITY ISSUES}

ISSN 2345-0282 (online) http://jssidoi.org/jesi/

2021 Volume 8 Number 3 (March)

http://doi.org/10.9770/jesi.2021.8.3(12)

place. Moreover, there is a shortage of specific and tested diagnostic tools (research instruments) to assess the changes in distance work and the impact on SMEs in the context of the COVID-19 economic constraints.

The aim of the research is to reveal the characteristics of distance work in small and medium business enterprises of Klaipeda Region in the context of COVID-19.

In order to achieve the goal, the following objectives have been set:

- $\quad$ To specify the concept of distance work;

- To analyse the changes in the nature of distance work under the COVID -19 circumstances;

- To define the specificity of distance work organisation by sector of activity (production, trade,or services);

- $\quad$ To highlight the advantages and disadvantages of distance work and its prospects.

\section{Review of phenomenon of distance work}

Distance work is a complicated and complex social phemonenon. The practices of recent years as well as research testified to a slow transition from the traditional to distance work organisation. The transition to distance work indicates also profound social and cultural changes that fundamentally modify not only the concept of work organisation but also of work itself. An essential trait of distance work is openness and provision of opportunities to work from different places and at different times. In order to analyse distance work, first of all, we need to look into a range of terms that are used to describe working from various other places than office. Telework, as a form of virtual work, involves working away from the office using computer technology to interact and communicate with others. Although the duration of teleworking time can vary, it generally involves working from home or another alternate location for part of a working week, spending the rest of the time in the corporate office. While telework often entails working from home, it also includes working from other remote locations such as a client office, airport, telework centre, or hotel (Golden, 2009). A number of various terms are currently in use to describe e-working, including: e-worker (mostly used in the UK), teleworking or teleworker and telecommuting (which originated in North America). All of these refer to the ability to work flexibly using remote technology to communicate with the workplace. Lately, agile working has been added to the terminology (Gillies, 2011). Telecommuting involves working solely from home instead of commuting to the office place (Golden, 2009). As defined by Grant at al. (2013), the term remote e-worker is used to describe individuals who use technology to work remotely from the main group office at any time or place. The terms like virtual teamwork, or telework, are most commonly operationalised as the dispersion of workers from their coworkers or teammates, including dispersion across locations, time, and/or organizational boundaries (Gilson, 2015). The term distance work refers to paid work that is done outside the actual workplace, such as at home or when travelling on the train, and generally involves use of information technology. By its nature, distance work can also be performed at the workplace. Sullivan (2003) states that homebased telework refers specifically to telework carried out from home and is further categorized based on frequency into regular, alternate and occasional.

The opportunity of working from nearly anywhere and at any time was enabled by an increased reliance upon technology to conduct work activities (Golden, 2009). Arvola at al. (2017) state that on the one hand, telework suits better to experienced employees as working alone is easier compared to less experienced employees and they need less help from the colleagues regarding their job-related issues on the other hand, older people have more challenges with using ICT. Technology has developed to such a degree that a large amount of work can be completed at any time of day or place, thus the terminology may not be quite as important as the actual working practices (Grant at al. 2019). Golden (2009) notes that teleworking and telecommuting involve computers with job-specific software, phones, and other handheld electronic devices as well as and high-speed remote access to corporate databases. Bathini and Kandathil (2019) argue that although as per the dominant discourse telework provides flexibility to employees, often, it is not effective in practice. On the contrary, for firms, telework 


\section{ENTREPRENEURSHIP AND SUSTAINABILITY ISSUES}

ISSN 2345-0282 (online) http://jssidoi.org/jesi/

2021 Volume 8 Number 3 (March)

http://doi.org/10.9770/jesi.2021.8.3(12)

provides flexibility in practice; yet, this employer benefit does not figure in the dominant discourse. Distant work can be kind of a tool to solve general unemployment problems. Hunton at al. (2010) after their research reported a positive association between organizational commitment and task performance across the treatment conditions and found that organizational commitment mediates the relationship between the telework arrangements and task performance. Fleetwood (2007) states that one causal factor that has received attention relates to working women. The (slight) changes in social attitudes and recent government attempts to "help" women back into work (driven as much by labour market shortages as a conversion to feminism) have encouraged millions of women to enter mainly part-time paid work. Both organizational adoption and employee participation in telework have a positive relationship with job satisfaction, and these results support the social exchange theory (Kwang at al., 2016). Kwang at al. (2016) also observe that the effects of decoupling of telework on job satisfaction are more significant for female public employees than for male public employees. Mas-Machuca at al. (2016) research findings suggest fostering organizational pride to increase job satisfaction and for companies to have the same proportion of women and men in high levels of responsibility due to problems related with work-life balance.

Remote e-working or distance working is usually associated with the positive effects of improved productivity, flexible approaches to work, a reduction in work-life conflict, and an increase in job satisfaction, many of these being mediated by a reduction in commuting aiding a better balance between work and non-working lives (Grant at all., 2013). Morganson at all. (2010) performed research that showed that main office and home-based workers had similar high levels of work-life balance (WLB) support and job satisfaction. Additionally, main office workers reported the highest levels of workplace inclusion (Morganson at al.,2010). Vitola at al. (2013) performed research in Latvia and research shows that the majority of working age people in cities as well as in rural areas is willing to be involved in telework and people in less populated areas are interested in socializing and networking activities. According to Vitola at al. (2013) smart work remains to be largely urban phenomena.

In Gallancherand and Hossain's (2020) estimation, 41\% of jobs in Canada can be done from home and, when weighted by wages, the percentage increases to 51\%; Dingel and Neiman (2020) estimate the percentage of jobs that can be done from home in the United States at 37 percent. Vrchota at al. (2019) analyzing telework in Czech companies found out that telework is more used in foreign companies (not specified whether it is a minority or majority share), for instance German companies.

\section{Research methodology}

The methodological paradigm was based on mixed-method research Creswell, John \& Plano Clark, Vicki (2011):

- Paradigm of quantitative research. Quantitative research is characterised by a large bulk of statistical data and employment of standardised procedures; numerical values are assigned to the research objects or their relationships. Quantitative research was applied to verify and confirm the essential features of the research and to substantiate causal connections of the phenomena statistically.

- $\quad$ Paradigm of qualitative research. Qualitative research was used with the purpose of describing the object, obtaining as many as possible diverse data and, based on them, generating ideas and highlighting problems.

The following methods were chosen to solve the research objectives:

- An analysis of scientific literature was performed to reveal the theoretical basis of the research problem; for the purpose, economic and sociological articles and publications on distance work in international scientific journals, databases, and the EU and the Republic of Lithuania documents on distance work regulation were analysed.

- A survey in writing (questionnaire) was used to interview representatives of business entities (SMEs managers and executives) to identify the situation and changes in distance work during the COVID-19 pandemic. (Authors' note: The total questionnaire was composed of four blocks of questions in order to find out: the 


\section{ENTREPRENEURSHIP AND SUSTAINABILITY ISSUES}

ISSN 2345-0282 (online) http://jssidoi.org/jesi/

2021 Volume 8 Number 3 (March)

http://doi.org/10.9770/jesi.2021.8.3(12)

information about the company and the changes in its economic activity and work organisation during the COVID -19 pandemic (March to July), the use of business support measures during the pandemic, and the impact of the state aid measures on business. Altogether, 48 structured- type questions were presented, two of them open-ended (including questions about the specific characteristics of distance work, the social- emotional climate in the workplace, etc.).

- The focus group approach (Denscombe, 2007) was used to reveal the diversity of concepts, attitudes, and opinions of the research participants (SME representatives, business association leaders, municipal representatives, and economic experts), reflecting on experiences of distance work. The topics of the focus group discussion were divided into 3 sub-themes, raising key questions: what concerns and difficulties of distance work were faced in the context of the COVID-19 pandemic; what changes had already taken place and what problems still needed to be addressed in order for the situation to change; which aspects of distance work should be given more attention and why; and what priorities could be anticipated in the future. The said topics made it possible to hear the participants' problems and needs as well as to have an in-depth glance and understand the differences in attitudes and opinions of the participants working in different business sectors.

- $\quad$ Statistical data analysis. Statistical analysis of the quantitative research datawas performed using Rstudio and MsExcel software for statistical data processing.

Research sample, characteristics, and organisation. The sample for the research was selected by a cluster sampling method.

The subgroups of the sample were defined in accordance to:

1. The location of SMEs in terms of municipality (seven municipalities: Klaipeda City, Klaipèda District, Kretinga District, Neringa City, Palanga City, and Skuodas and Šilute Districts).

2. $\quad$ SME activity sector (manufacturing, trade, or services).

In accordance with the data of the Lithuanian Department of Statistics (Statistics Lithuania), on 1 January 2020, 10,427 business entities operated in Klaipeda Region, including 1,041 in the manufacturing, 2,913 in trade, and 6,473 in services sectors.

In terms of the business structure in Western Lithuania, large business enterprises are concentrated in Klaipèda City, Klaipeda Free Economic Zone, and Klaipeda port territory. Somewhat larger concentration of SMEs in Klaipeda City can be accounted for by the fact that Klaipeda is is the largest city in the region, the third largest city in Lithuania, and the only national port city, and therefore it provides more business opportunities for companies working with international trade and logistics. Businesses in some individual areas, such as Palanga City and and Neringa City, mainly concentrate on tourism and accommodation services and are characterized by seasonality.

The empirical research (a written survey and focus group) was conducted in October-November 2020. The questionnaire was posted on the online platform at: https://forms.gle/tiyLRhyuteb4F6478 the survey lasted 5 weeks. Focus groups were organised using the Zoom platform.

73 business entities participated in the research (written survey), and seven focus group discussions were held (Klaipėda City, Klaipėda District, Palanga City, Šilute District, Skuodas District, Kretinga District, and Palanga City) with 61 participants (on average, eight participants in each group). The discussions were recorded; the total recording time was 6 hours. $17 \mathrm{~min}$ In the analysis of the data, the recording was listened to several times, transcribed in parts, and the data were systematised in accordance to meaningful units and summarised. The report presented the opinion of the informants and quoted their statements (the language style of the informants had been adjusted, given the norms of the standard language).

The organisation of the research, data analysis, and presentation of the research findings were performed in accordance with the ethical principles of qualitative research recommended by the ICC / ESOMAR (International Code on Market, Opinion and Social Research and Data Analytics) and the Code of Ethics of the Lithuanian Sociological Society. 


\section{Results}

Based on the survey findings (see Fig. 1), the vast majority of business entities had to change their way of operating and work organisation and to adapt to the current situation in one way or another; only a small part $(16.4 \%)$ of the surveyed companies indicated that they worked as usual, no changes took place, and the work was organised in a routine way.

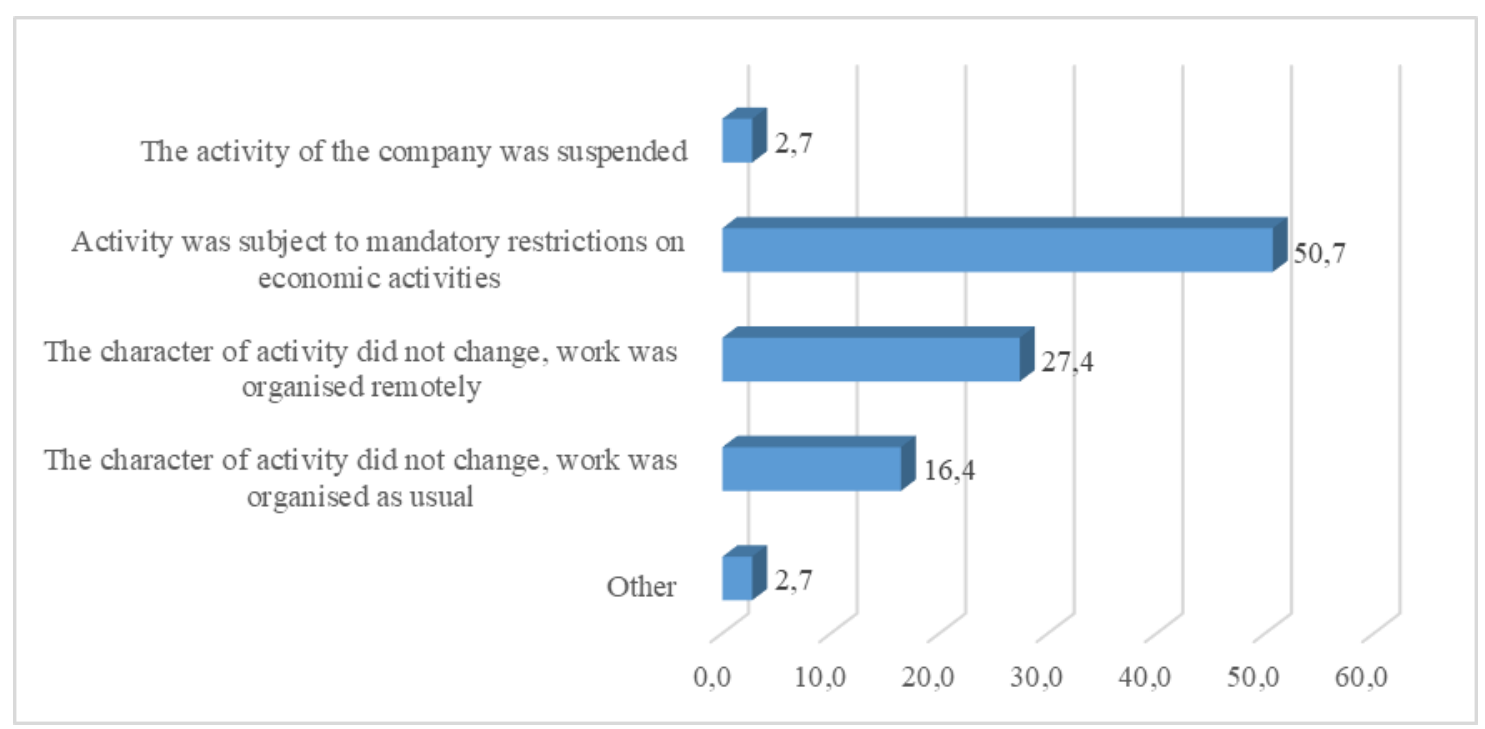

Figure 1. Company's operating situation after the announcement of the COVID-19 pandemic-related lockdown (per cent)

According to slightly more than half $(50.7 \%)$ of the surveyed respondents, during the pandemic, mandatory temporary restrictions on economic activity were introduced in companies from 16 March, i.e. downtime was declared, some employees were given leave of absence, and some were laid off. However, almost a third (27.4\%) of the respondents noted that, during the period in question, the personnel of the company worked completely remotely.

The non-parametric Kruskal-Wallis test (see Table 1) indicated statistically significant distance work-related differences between the sectors of manufacturing, of services where physical contact was required, of services where no physical contact was required, and of trade. Based on the median ranks, we concluded that, in enterprises where physical contact was not required for the provision of services (Mean rank-52.53), more work was done remotely. Interestingly, the workers of the manufacturing company (Mean rank-40.91) also worked remotely quite a lot of time. Since the respondents of the survey were managers or executives of the companies, we presume that they spoke on behalf of the administration, who were probably not directly involved in the production process and for whom the contact with customers / suppliers was not relevant. A similar situation was found in the case of services where physical contact was required: the findings evidenced that the lowest percentage of the personnel working remotely belonged to small and medium-sized trading companies.

Meanwhile, discussions in focus groups revealed that the personnel in the (non-contact) service sector worked remotely more often than those in the trade sector; and in the manufacturing sector, more workers remained in their regular workplaces during the lockdown period and worked remotely the least. 
Table 1. Differences in the extent of distance work, depending on business sector

\begin{tabular}{|c|c|c|c|c|}
\hline Sector & N & Mean rank & $\begin{array}{c}\text { Kruskal- } \\
\text { Wallis H }\end{array}$ & P-value \\
\hline Production & 11 & 40,91 & & \multirow{2}{*}{0,000} \\
\hline Services where contact is required & 34 & 32,18 & \\
\cline { 1 - 3 } Services where contact is not required & 18 & 52,53 & & \\
\hline Trade & 10 & 21,15 & & \\
\hline
\end{tabular}

In terms of changes in the nature of work organisation in the surveyed companies, almost $59 \%$ of the respondents stated that they all worked remotely to a greater or lesser extent; therefore, we can presume that distance work methods were used not only by the business entities that stated having applied distance work in the company during the Covid-19 pandemic, but also by those that claimed that their work organisation had not changed or that the company had been subject to economic restrictions.

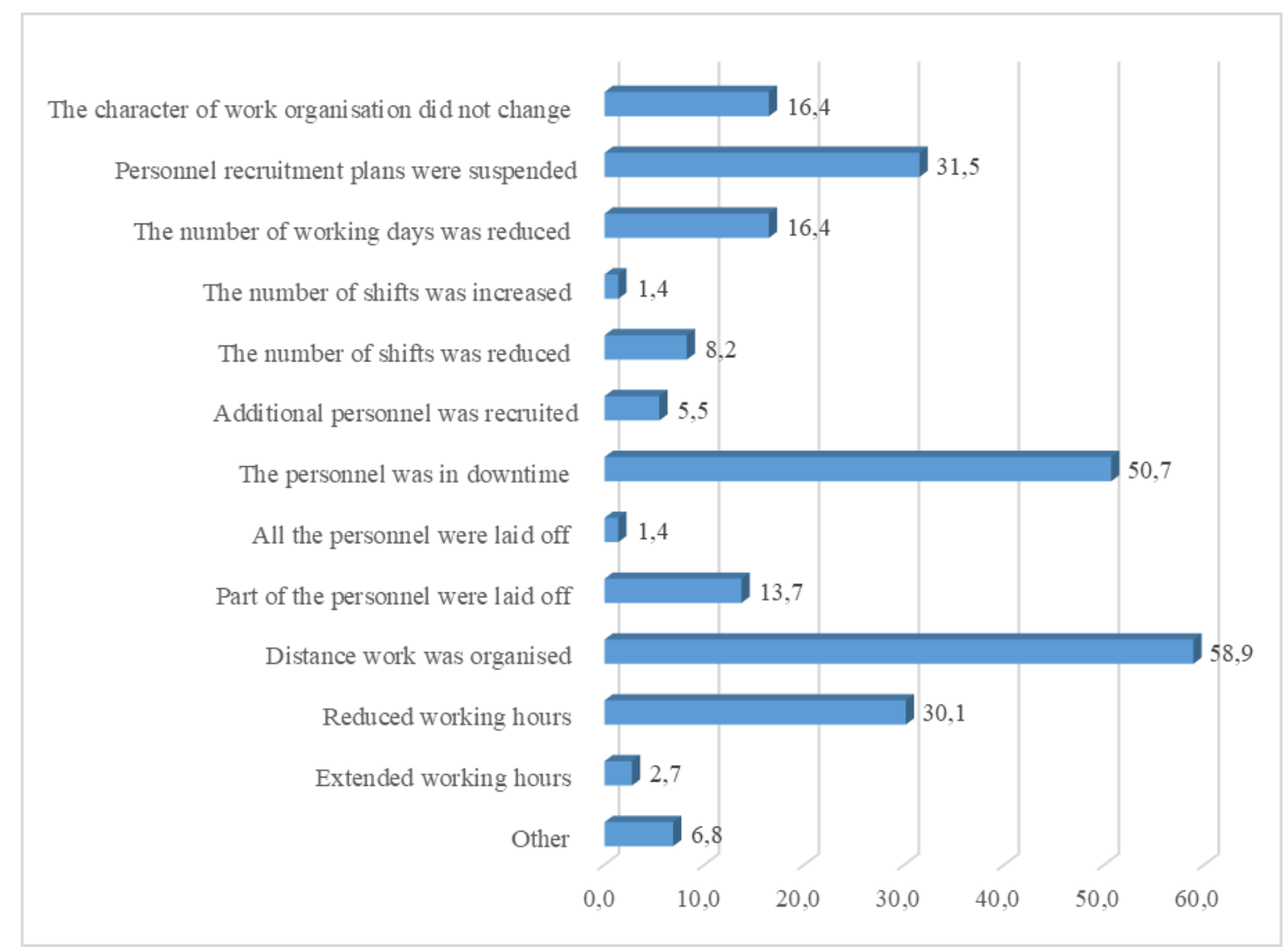

Figure 2. Nature of work organisation in company during the COVID-19 pandemic (per cent).

As indicated by the findings, in order to ensure employee retention and simultaneously to maintain the business, small and medium-sized enterprises used various individual distance work solutions (one third (30.1\%) of the business entities reduced contact working hours by changing them to work remotely, $16,4 \%$ reduced the number of working days by $4 \%$ (i.e. an employee worked remotely for one or more days per week), moreover, the personnel were provided with the necessary technical equipment and trained to use it. 


\section{ENTREPRENEURSHIP AND SUSTAINABILITY ISSUES}

ISSN 2345-0282 (online) http://jssidoi.org/jesi/

2021 Volume 8 Number 3 (March)

http://doi.org/10.9770/jesi.2021.8.3(12)

\subsection{Advantages and challenges of distance work}

Upon introduction of distance work organisation and/or mixed type of work, businesses encountered problems which, according to the participants of the discussions, were twofold: technical / practical and social / emotional. The focus groups interviews revealed that the main difficulties in distance work were related to insufficient / poor competencies required to use IT equipment and software efficiently as well as a lack of necessary equipment. That can be accounted for by the novelty of the elements of the virtual environment for the personnel and by their insufficient knowledge. The second problem in distance work and communication was related to emotional or psychological difficulties, overcoming the fear of ignorance, identification of real and virtual space, and an unusual work environment (i.e. when work moved to a home/family environment).

Table 2. Assessment of the personnel ability to work remotely (per cent)

\begin{tabular}{|l|l|}
\hline & Percent \\
\hline Positive & 42,3 \\
\hline More positive & 29,6 \\
\hline More negative & 14,1 \\
\hline Negative & 14,1 \\
\hline
\end{tabular}

Even though most of the representatives of the business entities participating in the quantitative survey evaluated the ability of the personnel to work remotely under changed conditions as generally good and very good (42.3\% and $29.6 \%$, respectively), one third of the respondents noted certain shortcomings and assessed it rather poor $(14.1 \%)$ or poor $(14.1 \%)$, respectively. The focus group discussions revealed that the personnel often/ more often named the advantages rather than the disadvantages of distance work. The more frequently identified advantages of distance work included: more flexible planning of work and rest time, a greater opportunity to pay attention to family, household, and housework, and the improved quality of life in general. In addition, the participants indicated records of meetings / conversations online (referring to the ZOOM platform) as a useful practice. We can presume that the possibility to view / listen to recordings at any time and as many times as desired (which is convenient because there is no need to take notes) makes the organisation of work activities more efficient. The difficulty in contacting the speaker during a video conference was also named, but that should be treated with caution, as a respondent may not have had sufficient courage to admit failure in dealing with a difficulty. The disadvantages named included the following: some people found it difficult to work from home due to the inability to plan time independently or a lack of self-motivation; it was often difficult to concentrate due to a lack of space in a small apartment, family distraction, the need to adjust to family members, etc. Several participants named work organisation-related problems (the indefiniteness of tasks and deadlines or a lack of activity regulation and coordination).

Table 3. Distance work challenges in small and medium sized enterprises (per cent)

\begin{tabular}{|l|c|c|c|c|c|}
\hline Activity sector & $\begin{array}{c}\text { Difficulty in controlling } \\
\text { personnel work and } \\
\text { performance in remote } \\
\text { working }\end{array}$ & $\begin{array}{c}\text { Lack of computer } \\
\text { equipment, Internet } \\
\text { quality issues, lack of } \\
\text { software }\end{array}$ & $\begin{array}{c}\text { Additional costs } \\
\text { for training } \\
\text { personnel to work } \\
\text { from home }\end{array}$ & $\begin{array}{c}\text { Dificulty in personnel } \\
\text { communication and } \\
\text { cooperation }\end{array}$ & $\begin{array}{c}\text { Difficulties } \\
\text { caused by } \\
\text { flexible } \\
\text { schedules }\end{array}$ \\
\hline Production & $0 \%$ & $0 \%$ & $40,0 \%$ & $40,0 \%$ & $20,0 \%$ \\
\hline $\begin{array}{l}\text { Services where } \\
\text { contact is required }\end{array}$ & $19,4 \%$ & $9,7 \%$ & $29,0 \%$ & $32,3 \%$ \\
\hline $\begin{array}{l}\text { Services where } \\
\text { contact is not } \\
\text { required }\end{array}$ & $22,2 \%$ & $16,7 \%$ & $22,2 \%$ & $33,3 \%$ \\
\hline Trade & $20,0 \%$ & $0 \%$ & $40,0 \%$ & $5,6 \%$ \\
\hline
\end{tabular}




\section{ENTREPRENEURSHIP AND SUSTAINABILITY ISSUES}

ISSN 2345-0282 (online) http://jssidoi.org/jesi/

2021 Volume 8 Number 3 (March)

http://doi.org/10.9770/jesi.2021.8.3(12)

Individual discussion participants believed that distance work was sometimes hampered by the individual negative attitudes, emotions, psychological resistance to the current reality, inability to adapt to the current situation, or even the age (older people found it more difficult to master technology). Still others mentioned communication difficulties when working remotely: a lack of consistent / matter-of-fact speaking skills (deviating to emotions), sometimes it was difficult to coordinate the conversation (several people speaking at the same time caused a commotion and made it difficult to hear), it was difficult to intervene, turn taking in discussion was disturbed, etc.).

The analysis of the quantitative survey data by sector of activity revealed that the representatives of the production sector experienced difficulties in communication and cooperation when working remotely (40\%); moreover, additional costs were incurred due to training the personnel to work from home (40\%); the same figure was indicated by the entrepreneurs from the trade sector (for more details, see Table 2). The situation was the opposite with IT equipment; according to the respondents, there was no shortage of computer hardware or software in all sectors of activity (production, trade, and services), and the Internet network worked well enough / efficiently. Only a small percentage of the business entities in the service sector noted such shortcomings $(16.7 \%$ of the respondents from contact services and $9.7 \%$ from non-contact services). No statistically significant differences were found after applying the variable independence (Chi-square) test (Chi-square $=8.743 ; \mathrm{p}=$ $0.725)$.

Table 4. Averages in the assessment of changes in distance work in enterprises

\begin{tabular}{|l|l|l|}
\hline $\begin{array}{l}\text { To what extent do you agree with the statements on the COVID-19 impact on your } \\
\text { company's operation? }\end{array}$ & Average & St. deviation \\
\hline Changed/ updated technology & 2,15 & 1,19 \\
\hline Improved skills to use IT equipment/ software & 2,38 & 1,25 \\
\hline
\end{tabular}

The responses about the changes in distance work (medians of assessment) testified to no significant updates and / or changes in technology in SMEs during the COVID-19 pandemic (A-2.15) (see Table 3 and Table 4). When assessing the ability of the personnel to use IT equipment and software (A-2.38), company executives did not notice any significant improvement, they assessed it with reservation (A-2.38).

The research also sought to reveal the correlation between variables, cf. Table 5. No statistically significant correlation was found between the updating of technology and the duration of the company's activity and the company's annual turnover.

Table 5. Correlation between distance work in an enterprise and the duration of the company's activity and the annual turnover.

\begin{tabular}{|l|c|c|}
\hline & Duration of company's activity & Annual turnover \\
\hline Updated technology & 0,036 & 0,120 \\
\hline Increase in online sales & 0,139 & $\mathbf{3 4 8}^{\text {** }}$ \\
\hline Improved skills of IT equipment/ software use & 0,140 & $\mathbf{2 4 7}^{*}$ \\
\hline
\end{tabular}

* correlation significant with 0.05 level of significance

** correlation significant with 0.01 level of significance

A statistically significant and direct correlation was established between the improved skills of the personnel to use IT tools / software, the annual turnover of the company, and the increase in online sales and the annual turnover. In other words, the higher the company's annual turnover, the more their online sales grew and the better the personnel's skills in using IT equipment and software were. No correlation existed between the skills of distance work and online sales and the duration of the company's activity.

Importance of social contacts in company was also evidenced by the results of the quantitative research. The median of the assessment of the fear to lose social contacts as a threat to business was rather low (A-4,12), i.e. in 


\section{ENTREPRENEURSHIP AND SUSTAINABILITY ISSUES}

ISSN 2345-0282 (online) http://jssidoi.org/jesi/

2021 Volume 8 Number 3 (March)

http://doi.org/10.9770/jesi.2021.8.3(12)

the fourth place after the assessment of the impact of the global economic downturn (A-4.26), the negative effects of the pandemic in general (A-4.23), and the threat of a new wave of COVID-19 (A-4, 14) (see Table 6).

Table 6. COVID-19-caused threats to the business environment

\begin{tabular}{|c|c|c|}
\hline $\begin{array}{l}\text { To what extent do you agree with the statements on the COVID-19 } \\
\text { impact on your company's operation? }\end{array}$ & Average & St. deviation \\
\hline Negative financial impact of the pandemic & 4,23 & 0,72 \\
\hline Impact of the global economic downturn & 4,26 & 0,69 \\
\hline Decrease in labour productivity & 3,77 & 0,99 \\
\hline Decrease in consumption & 3,85 & 0,95 \\
\hline Fear of losing social contact & 4,12 & 0,88 \\
\hline Supply chain disruptions & 3,81 & 0,94 \\
\hline Fear of infection & 3,97 & 0,93 \\
\hline A new wave of COVID-19 & 4,14 & 0,80 \\
\hline Cyber security risks & 3,60 & 0,88 \\
\hline Ability to efficiently work remotely & 3,23 & 0,99 \\
\hline Increased business costs due to the adjustment of workplaces & 3,90 & 0,96 \\
\hline Lack of prompt information & 3,70 & 1,00 \\
\hline Lack of state aid measures for business & 3,64 & 1,23 \\
\hline Inefficiency of state aid measures for business & 3,62 & 1,11 \\
\hline
\end{tabular}

Regarding the lack of social communication (in other words, social exclusion), which negatively affected the personnel emotions and general condition, the findings of the research revealed that the company executives and administration made a great effort to compensate for it (see Table 7).

Table 7. Action of the company executives / administration to support the personnel in the context of changed working conditions

\begin{tabular}{|l|c|c|}
\hline $\begin{array}{l}\text { To what extent do you agree with the statements on informing the personnel } \\
\text { about the changes in working conditions? }\end{array}$ & Average & St. deviation \\
\hline $\begin{array}{l}\text { We explained to the personnel the possibilities of state support and measures and } \\
\text { the mechanism of their operation }\end{array}$ & 3,59 & 0,97 \\
\hline We consulted and trained the personnel to work remotely & 3,11 & 1,25 \\
\hline We reminded the personnel of the rules of hygiene to prevent infection & 4,34 & 0,80 \\
\hline $\begin{array}{l}\text { We informed about travel restrictions (changes in business trips and / or work in } \\
\text { another country) }\end{array}$ & 3,90 & 1,17 \\
\hline $\begin{array}{l}\text { We shared information about the current situation and possible business change } \\
\text { plans }\end{array}$ & 4,01 & 0,96 \\
\hline We tried to maintain a positive emotional work climate & 4,27 & 0,79 \\
\hline
\end{tabular}

The managers and executives of the SMEs argued that not only did they take care of the health of the personnel (regarding hygiene rules, keeping a safe distance, use of protective equipment, etc.), but also regularly shared information about the current situation and possible business change plans with them (A-4.01). Accordingly, a large number of business entities tried to maintain a positive emotional climate in workplaces (A-4.27); the executives were concerned about the psychological state and mood of the personnel. The qualitative research, i.e. the focus group participants, confirmed the statistical facts that it was important for the executives and administration to share information with the personnel, to maintain their emotional stability, to manage or, in other words, to reduce the resulting psychological stress in companies, etc. Thus, a business representative in the catering sector said: "It was scary because of the drop in the income, we had to readjust promptly, and that period in our catering company was associated with emotional stress. We communicated with the personnel, and first of all tried to overcome the emotional and psychological difficulties". According to another respondent, "The people experienced fear about the future, income security, fear of losing a job, and fear of getting sick." Efforts to maintain a positive emotional climate in the workplace were significantly more important (A-4.27) than, e.g., 
training the personnel to work remotely (A-3.11), explaining state support measures (A-3.59), or sharing information about possible changes in business plans (A-4.01) (for more detail, see Table 7 ).

The analysis of the correlations and the application of the Kruskall-Wallis criterion did not reveal any significant differences between the measures taken to inform the personnel and the company's sector of activity (see Table 8).

Table 8. Personnel information dependence on/ differences in by company's sector of activity

\begin{tabular}{|c|c|c|c|c|c|}
\hline & Sector & $\mathbf{N}$ & $\begin{array}{l}\text { Mean } \\
\text { ranks }\end{array}$ & $\begin{array}{l}\text { Kruskal- } \\
\text { Wallis H }\end{array}$ & P-value \\
\hline \multirow{4}{*}{$\begin{array}{l}\text { We explained to the } \\
\text { personnel about the } \\
\text { opportunities of the state } \\
\text { support and measures and } \\
\text { the mechanism of their } \\
\text { operation }\end{array}$} & Production & 11 & 27,86 & \multirow{4}{*}{3,44} & \multirow{4}{*}{0,33} \\
\hline & Services where contact is required & 34 & 39,07 & & \\
\hline & Services where contact is non-required & 18 & 40,31 & & \\
\hline & Trade & 10 & 34,05 & & \\
\hline \multirow{4}{*}{$\begin{array}{l}\text { We consulted and trained } \\
\text { the personnel to work } \\
\text { remotely }\end{array}$} & Production & 11 & 39,64 & \multirow{4}{*}{6,86} & \multirow{4}{*}{0,07} \\
\hline & Services where contact is required & 34 & 33,91 & & \\
\hline & Services where contact is non-required & 18 & 46,42 & & \\
\hline & Trade & 10 & 27,65 & & \\
\hline \multirow{4}{*}{$\begin{array}{l}\text { We reminded employees of } \\
\text { the rules of hygiene to } \\
\text { prevent infection }\end{array}$} & Production & 11 & 33,23 & \multirow{4}{*}{1,64} & \multirow{4}{*}{0,65} \\
\hline & Services where contact is required & 34 & 40,00 & & \\
\hline & Services where contact is non-required & 18 & 34,33 & & \\
\hline & Trade & 10 & 35,75 & & \\
\hline \multirow{4}{*}{$\begin{array}{l}\text { We informed about travel } \\
\text { restrictions (changes in } \\
\text { business trips and / or work } \\
\text { in another country) }\end{array}$} & Production & 11 & 40,77 & \multirow{4}{*}{0,46} & \multirow{4}{*}{0,92} \\
\hline & Services where contact is required & 34 & 36,46 & & \\
\hline & Services where contact is non-required & 18 & 36,33 & & \\
\hline & Trade & 10 & 35,90 & & \\
\hline \multirow{4}{*}{$\begin{array}{l}\text { We shared information } \\
\text { about the current situation } \\
\text { and possible business } \\
\text { change plans }\end{array}$} & Production & 11 & 32,14 & \multirow{4}{*}{2,63} & \multirow{4}{*}{0,45} \\
\hline & Services where contact is required & 34 & 40,78 & & \\
\hline & Services where contact is non-required & 18 & 34,36 & & \\
\hline & Trade & 10 & 34,25 & & \\
\hline \multirow{4}{*}{$\begin{array}{l}\text { We tried to maintain a } \\
\text { positive emotional work } \\
\text { climate }\end{array}$} & Production & 11 & 29,27 & \multirow{4}{*}{5,45} & \multirow{4}{*}{0,14} \\
\hline & Services where contact is required & 34 & 41,76 & & \\
\hline & Services where contact is non-required & 18 & 36,78 & & \\
\hline & Trade & 10 & 29,70 & & \\
\hline
\end{tabular}

\subsection{Distance work as a priority area in the future}

The research testified to most small and medium-sized businesses having been quite successful in overcoming technological difficulties that had seemed serious from the outset. During the focus group discussion, some business representatives indicated that they would prefer to work remotely in the future, while others were willing to combine distance and face-to-face work (mixed work organization) (note: more representatives from the services than from the business sector were willing to work remotely). 


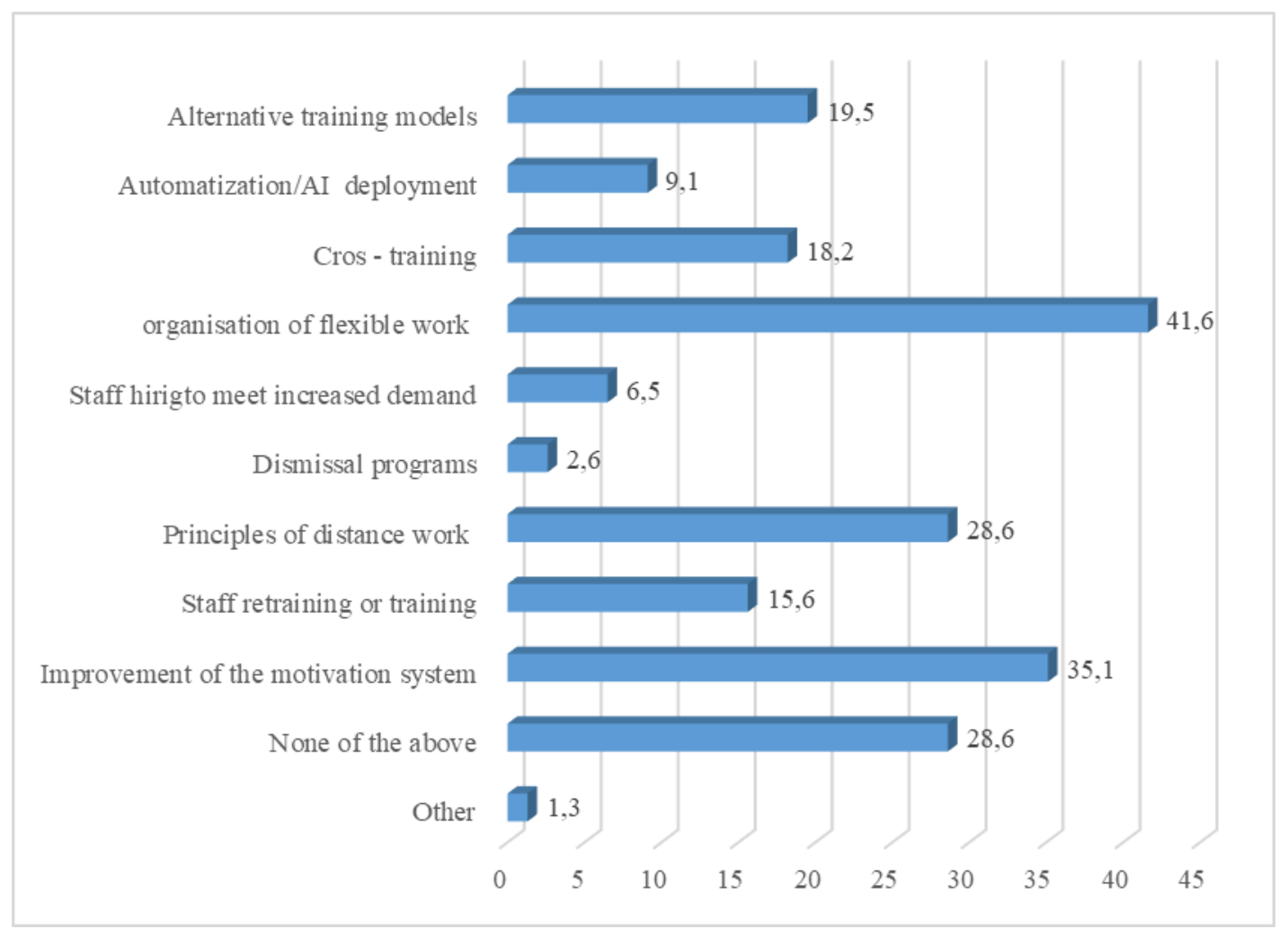

Figure 3. Priorities set by companies for the period of the next three to six months

The quantitative research revealed (see Figure 3) that the executives of business entities identified the following priority areas for the next three to six months: organisation of flexible work (41.6\%), improvement of the motivation system at work (35.1\%), and introduction of distance work principles $(28.6 \%)$. The organisation of flexible work was closely linked to the enabling of distance work in companies, and one of the components of the motivation system was likely to be flexible working practices.

Moreover, focus group discussions highlighted the importance of investment (with the state providing support in the area as well) in new IT tools focused on the business of the future: "to invest in tools that allow distance work and to offer new innovative services". It should be added that the development of new and innovative services is also impossible without new IT technology. As priority areas for business support, the participants of the focus groups identified the enabling of distance work: "It is not known how long the second lockdown will last and what its impact on the company's operations will be, therefore, support for the creation of distance workplaces is important (i.e. computer mobile workstations - the equipment and coverage of the Internet services). In addition, the representatives of the businesses believed that the development of the personnel's IT knowledge and skills created proper preconditions for distance work: that would contribute to opening up new opportunities through a variety of online work organisation media. The choice of the most suitable distance work methods, the ability to combine work and leisure, to control the work independently, and to increase the internal motivation created preconditions for more efficient distance work in the future.

\section{Discussion and conclusions}

Distance work can be evaluated in very different ways. Working from home or anywhere may cause various problems, and not all the personnel will react to the same situation in the same way. Leonardi at al. (2010) found 


\section{ENTREPRENEURSHIP AND SUSTAINABILITY ISSUES}

ISSN 2345-0282 (online) http://jssidoi.org/jesi/

2021 Volume 8 Number 3 (March)

http://doi.org/10.9770/jesi.2021.8.3(12)

out that individuals using the same communication tool may experience different degrees of perceived distance. Eckhardt at al. (2019) in their research established that quite a few companies did not appear to fully appreciate the consequences of the operation of virtual workers, especially the blurring of the boundaries between their professional and private lives. Moreover, in other studies, distance work associated with poor general condition, workplace pressure, and communication overload, all of which might lead to over-working able to subsequently affect job performance and effectiveness (Barber, Santuzzi, 2015). Suciu (2020) noted that the emergence of COVID 19 had created new challenges for cybersecurity and information security risk management.

Due to the COVID-19 pandemic, many teams who had enjoyed the benefits of working in the same physical space became virtual teams overnight. Teams dealing with an unplanned transition to distance work needed help, especially with accomplishing work that required interdependent, coordinated effort (Bendaly, 2020). Sanjeewa (2020) argued that team leaders needed to understand how trust and psychological safety were fostered and maintained in their teams. They needed to take care not to stifle the informal aspects of teamwork. Burrell (2020) believed that managers needed to keep reminding members of the team of the need to adapt and change roles and responsibilities. According to Sanjeewa (2020), team leaders had to ensure the possibility for team members to approach them with proposals or concerns. Teams usually had preferences about how quickly members had to respond and which modes of communication should be used (Bendaly, 2020).

Dixon and Panteli (2010) observed that teams could actually use technology-mediated communication to bridge discontinuities (e.g. internal or organisational differences) among team members. Brown at al. (2020) stated that, unlike prior experimental studies that focused on the detrimental effects of computer-mediated communication, modern technologies were often used to enable team functioning. The technology used for communication in a virtual team needed to provide as many types of media as possible to facilitate timely communication and foster bonds within the team to allow for work to be done effectively and with positive participation (Sanjeewa, 2020). Bunce, Wright and Scott (2018) indicated that quite a few workplaces had adopted new technological tools designed to facilitate communication among team members, such as Slack or Microsoft Teams. According to Laitinen and Valo (2018), those tools, along with other traditional means of communication (e.g. e-mail or instant message), allowed teams with an equivalent degree of objective dispersion to vary greatly in the ways in which their members interacted. Thus, two teams performing the same task with members who were equally dispersed could use a different combination of tools and experience dramatically different levels of virtuality.

The expectations of business executives in Western Lithuania and Klaipeda Region regarding distance work were basically in line with the traditions of the developed European countries and were justified, especially in the context of the EU Digital Agenda and the European Green Deal. The personnel who had tried to work remotely saw more of its advantages than disadvantages. In addition, the advantages of distance work were essential: it enabled working people to pay more attention to their families and household chores and improved the quality of life. Meanwhile, most of the negative aspects of distance work were related to the issues of communication, organisation, and technology and could be easily addressed by providing the personnel with appropriate tools and paying sufficient attention to communication and the methodology and organisation of distance work.

\section{References}

Arvola, R., Tint, P. \& Kristjuhan, U. (2017). Employer attitude towards telework in real estate sector, In Economic Science For Rural Development (pp. 15-22). Jelgava: Latvian University of Life Sciences.

https://llufb.1lu.1v/conference/economic_science_rural/2017/Latvia_ESRD_46_2017-15-22.pdf

Barber, K.L., Santuzzi, A.M. (2015). Please respond ASAP: workplace telepressure and employee recovery. Journal of Occupational Health Psychology, 20(2), 172-189, http://dx.doi.org/0.1037a0038278 


\section{ENTREPRENEURSHIP AND SUSTAINABILITY ISSUES}

ISSN 2345-0282 (online) http://jssidoi.org/jesi/

2021 Volume 8 Number 3 (March)

http://doi.org/10.9770/jesi.2021.8.3(12)

Bathini D. R., Kandathil G. M. (2019). An Orchestrated Negotiated Exchange: Trading Home-Based Telework for Intensified Work. Bus Ethics (2019) 154:411-423 https://doi.org/10.1007/s10551-017-3449-y

Bendaly, N. (2020). Your Team Is Now Working Remotely 5 Ways to Strengthen Communication and Team Cohesion in the COVID-19 World, Forbes https://www.forbes.com/sites/nicolebendaly/2020/03/20/your-team-is-now-working-remotely5-ways-to-strengthencommunication-and-team-cohesion-in-the-covid-19-world/?sh=6d681eb85b70

Brown Matt I., Prewett Matthew S., Grossenbacher Michael A. (2020). Distancing Ourselves From Geographic Dispersion: An Examination of Perceived Virtuality in Teams. Group Dynamics: Theory, Research, and Practice. American Psychological Association, 24(3), 168 -185 ISSN: 1089-2699 http://dx.doi.org/10.1037/gdn0000120

Bunce, M., Wright, K., Scott, M. (2018). Our newsroom in the cloud: Slack, virtual newsrooms and journalistic practice. New Media \& Society, 20, 3381-3399. http://dx.doi.org/10.1177/1461444817748955

Burbules, N. C., Callister, T. A. (2000). Universities in Transition: The promise and the challenge of new technologies. Teachers College Record, 102(2), 271-293 https://doi.org/10.1111/0161-4681.00056

Burrell D. N. (2020). Understanding The Talent Management Intricacies Of Remote Cybersecurity Teams In Covid-19 Induced Telework Organizational Ecosystems. Revista Academiei Forţelor Terestre, 3(99) https://doi.org/10.2478/raft-2020-0028

Creswell, J., Plano Clark, Vicki. (2011). Designing and conducting mixed methods research (2nd ed.). Thousand Oaks, CA: Sage.

Denscombe, M. (2007). The good research guide for small-scale social research projects. (3rd ed.). New York: McGraw-Hill.

Dingel J.I. , Neiman B. (2020). How Many Jobs Can Be Done at Home? NBER Working Paper No. 26948. Cambridge, MA: National Bureau of Economic Research https://www.nber.org/system/files/working papers/w26948/revisions/w26948.rev0.pdf

Dixon K.R., Panteli, N. (2010). From virtual teams to virtuality in teams. Human Relations, 63, 1177-1197. http://dx.doi.org/10.1177/0018726709354784

Draft Law No XII-2462 on the Approval, Coming into Force and Implementation of the Labour Code of the Republic of Lithuania. 21 June 2016 https://e-seimas.lrs.lt/portal/legalAct/lt/TAD/da9eea30a61211e8aa33fe8f0fea665f?jfwid=-k3id7tf7e

Eckhardt A., Giordano A., Endter F., Somers P. (2019). Three Stages to a Virtual Workforce. MIS Quarterly Executive, 18(1) http://docplayer.net/136068266-Three-stages-to-a-virtual-workforce-1.html

Fleetwood S. (2007). Why work-life balance now? The International Journal of Human Resource Management, 18(3), 387-400. https://doi.org/10.1080/09585190601167441

Gallacherand G., Iqbal H. (2020). Remote Work and Employment Dynamics under COVID-19: Evidence from Canada. Canadian Public Policy / Analyse de politiques, http://dx.doi.org/10.3138/cpp.2020-026

Gillies, D. (2019). Agile bodies: a new imperative in neoliberal governance. Journal of Education Policy, 26(2), 207-223, http://dx.doi.org/10.1080/02680939.2010.508177

Gilson, L. L., Maynard, M. T., Young, N. C. J., Vartiainen, M., \& Hakonen, M. (2015). Virtual teams research: 10 years, 10 themes, and 10 opportunities. Journal of Management, 41, 1313-1337. http://dx.doi.org/10.1177/0149206314559946

Golden T. D. (2009). Applying technology to work: toward a better understanding of telework. Organization Management Journal, 6, 241250 https://doi.org/10.1057/omj.2009.33

Grant Ch.A., Wallace L.M., Spurgeon P.C., Tramontano C., Charalampous M. (2019). Contruction and initial validation of the E-Work Life Scale to measure remote e-working, Employee Relations, 41(1), 16-33. http://dx.doi.org/10.1108/ER-09-2017-0229 


\section{ENTREPRENEURSHIP AND SUSTAINABILITY ISSUES}

ISSN 2345-0282 (online) http://jssidoi.org/jesi/

2021 Volume 8 Number 3 (March)

http://doi.org/10.9770/jesi.2021.8.3(12)

Grant, C.A., Wallace, L.M. and Spurgeon, P.C. (2019). An exploration of the psychological factors affecting remote e-worker's job effectiveness, well-being and work-life balance. Employee Relations, 5(35), 527-546, http://dx.doi.org/10.1108/ER-08-2012-0059

Gruževskis, B. (2001). Užimtumo pokyčiai. Lanksčių užimtumo formų taikymo galimybių įvertinimas (Changes in employment. Assessment of the possibilities of applying flexible forms of employment). Vilnius: Justitia https://vb.1stc.1t/object/elaba:25724454/25724454.pdf

Hunton J.E., Norman C.S. (2010). The Impact of Alternative Telework Arrangements on Organizational Commitment: Insights from a Longitudinal Field Experiment. Journal of Information Systems 24 (1): 67-90. https://doi.org/10.2308/jis.2010.24.1.67

Kwang B.B., Dohyeong K. (2016). The Impact of Decoupling of Telework on Job Satisfaction in U.S. Federal Agencies: Does Gender Matter? The American Review of Public Administration. Vol.46 issue: 3. https://doi.org/10.1177/0275074016637183

Kwon M., Jeon S.H. (2020). Do Leadership Commitment and Performance-Oriented Culture Matter for Federal Teleworker Satisfaction With Telework Programs? Review of Public Personnel Administration, Vol. 40(1) 36-55 https://doi.org/10.1177/0734371X18776049

Laitinen, K., Valo, M. (2018). Meanings of communication technology in virtual team settings: Framing technology-related interaction. International Journal of Human-Computer Studies, 111, 12-22. http://dx.doi.org/10.1016/j.ijhcs.2017.10 .012

Leonardi P. M., Treem J. W., Jackson, M. H. (2010). The connectivity paradox: Using technology to both decrease and increase perceptions of distance in distributed work. Journal of Applied Communication Research, 38, 85-105.

http://dx.doi.org/10.1080/00909880903483599

Mas-Machuca M., Berbegal-Mirabent J., Alegre I. (2016). Work-life balance and its relationship with organizational pride and job satisfaction. Journal of Managerial Psychology. https://doi.org/10.1108/JMP-09-2014-0272

Miežienė R., Gruževskis B. (2016). Atypical Forms of Employment in Lithuania: Main Characteristics and Prevalence, Socialiniai tyrimai / Social Research. 39(1), 27-36 https://doi.org/10.21277/sc.v1i39.76

Morganson, V.J., Major, D.A., Oborn, K.L., Verive, J.M., Heelan, M.P. (2010). Comparing telework locations and traditional work arrangements: Differences in work-life balance support, job satisfaction, and inclusion, Journal of Managerial Psychology, 25(6), 57895. https://doi.org/10.1108/02683941011056941

Nakrošienè A., Butkevičienè E. (2016). Telework in Lithuania: the concept, benefits and challenges to the employees, Filosofija. Sociologija, 2027(4), 364-372. https://www.researchgate.net/publication/318273903

Sanjeewa S. (2020). Trust and psychological safety in a virtual healthcare team. World Family Medicine, 18(9), 53-57. http://dx.doi.org/10.5742MEWFM.2020.93855

Suciu, P. (2020). COVID-19 and Computer Security, Part 2: Shoring Up Systems for Remote Workers. Tech News World https://www.technewsworld.com/story/86579.html

Sullivan, C. (2003). What's in a name? Definitions and conceptualisations of teleworking and homeworking. New Technology, Work and Employment, 18(3), 158-165. https://doi.org/10.1111/1468-005X.00118

Vitola A., Baltina I. (2013). An Evaluation of the Demand for Telework and Smart Work Centres in Rural Areas: A Case Study from Latvia. European Countryside, Volume 5: Issue 3. https://doi.org/10.2478/euco-2013-0016

Vrchota J., Frantikova Z., Vlčkova M., (2019). Why Some SME's in the Czech Republic Adopt Telework and Others Not? European Countryside, 11(4). https://doi.org/10.2478/euco-2019-0033 


\section{ENTREPRENEURSHIP AND SUSTAINABILITY ISSUES}

ISSN 2345-0282 (online) http://jssidoi.org/jesi/

2021 Volume 8 Number 3 (March)

http://doi.org/10.9770/jesi.2021.8.3(12)

\section{Acknowledgements}

This research was funded by Lithuania Research Council, grant number P-COV-20-5

Giedrè STRAKŠIENE், PhD, is a senior researcher at Klaipeda University, her research interest: communication, development of communicative competence, information visualization.

ORCID ID: https://orcid.org/0000-0001-8533-0276

Henrika RUGINE் is a lecturer at Klaipeda university, her research interests: e-work, green economy, labour market ORCID ID: https://orcid.org/0000-0002-7794-3977

Laura ŠALTYTÉ-VAISIAUSKE் PhD, is an associate professor at Klaipėda University, her research interests: statistics, econometrics, big data analytics.

ORCID ID: https://orcid.org/0000-0003-2210-1649

Make your research more visible, join the Twitter account of ENTREPRENEURSHIP AND SUSTAINABILITY ISSUES: @Entrepr69728810

Copyright (C) 2021 by author(s) and VsI Entrepreneurship and Sustainability Center

This work is licensed under the Creative Commons Attribution International License (CC BY).

http://creativecommons.org/licenses/by/4.0/

c) (7) Open Access 